Revue de sciences sociales sur les arts, la culture et les idées

\title{
2 | 2018
}

Arpenter la vie littéraire

\section{A Few Questions About Chronopéra}

Quelques questions sur Chronopéra

Algunas interrogaciones sobre Chronopéra

\section{Solveig Serre}

Translator. Michelle Arriss, Delaina Haslam and Séverine Sofio

\section{OpenEdition}

\section{Journals}

Electronic version

URL: http://journals.openedition.org/bssg/209

DOI: $10.4000 /$ bssg.209

ISSN: 2490-9424

\section{Publisher}

Presses universitaires de Vincennes

\section{Electronic reference}

Solveig Serre, "A Few Questions About Chronopéra", Biens Symboliques / Symbolic Goods [Online], 2 | 2018, Online since 12 April 2018, connection on 04 March 2021. URL: http://journals.openedition.org/ bssg/209 ; DOI: https://doi.org/10.4000/bssg.209 


\title{
Quelques questions sur Chronopéra A Few Questions About Chronopéra
}

\author{
Solveig Serre \\ traduction | translation \\ Michelle Arriss | Delaina Haslam | Séverine Sofio
}

\section{Comment est né le projet de base de données ?}

La base de données Chronopéra est l'un des projets pionniers dans le champ de la publication des recherches sur l'histoire des spectacles au moyen des nouvelles technologies. Elle est issue de la rencontre, en 2003, de trois chercheurs au CNRS : Michel Noiray, (musicologie, Institut de recherche en musicologie), Solveig Serre (musicologie, Centre d'études supérieures de la Renaissance) et Olivier Serre (informatique théorique, Institut de recherche en informatique fondamentale). Elle doit sa création à la volonté d'élaborer un outil statistique au service de l'interprétation historique. En reconstituant la chronologie de l'intégralité des représentations données par l'Opéra de Paris depuis 1669, elle a pour objectif principal de proposer une interprétation des événements et des tendances de la création lyrique au sein de cette institution et présente un triple intérêt : éclairer des questions

\section{How did the database project begin?}

The Chronopéra database is one of the pioneering projects in the history of performing arts using digital technologies to make research available online. It is the result of a meeting in 2003 between three CNRS researchers: Michel Noiray (musicology, Institut de recherche en musicologie), Solveig Serre (musicology, Centre d'études supérieures de la Renaissance), and Olivier Serre (theoretical data processing, Institut de recherche en informatique fondamentale). Its creation was triggered by the desire to build a statistical tool for historical interpretation. In reconstituting the chronology of all the performances given by the Opéra de Paris from 1669, its primary aim is to suggest an interpretation of events and tendencies of lyric creation within this institution; its usefulness is threefold: to clarify issues of reception by revealing what the public went to see in a given period; to measure the 
de réception en permettant de savoir ce qu'allait voir le public à une époque donnée, mesurer l'effet de nouveauté en faisant apparaître le contexte général dans lequel surviennent les créations, faire ressortir la manière dont l'Opéra conçoit sa stratégie artistique en confrontant les intentions des directeurs de l'Opéra et des différents responsables de production. Conçue comme un outil de travail, aisément accessible au chercheur, enrichissant constamment son contenu et se situant à la croisée de deux domaines de recherche trop souvent séparés - l'histoire institutionnelle et I'histoire des œuvres -, Chronopéra s'impose ainsi comme une mine documentaire et un outil de travail indispensable pour des historiens de la musique, de la danse et du spectacle.

\section{Comment le corpus a-t-il été délimité ?}

Chronopéra fournit le répertoire journalier de l'Opéra de Paris depuis sa création, en 1669, jusqu'en 1989, date de l'inauguration de l'Opéra Bastille. II s'agit donc d'un corpus clos et homogène, ce qui se justifie d'autant mieux que l'Opéra de Paris constitue dès l'origine son répertoire comme un fonds où les œuvres restent durablement présentes. Pour autant, la reconstitution de ce répertoire n'est pas aisée du point de vue archivistique car à la différence d'autres grandes institutions culturelles comme la Comédie-Française, l'Opéra de Paris n'a pas bénéficié d'une gestion continue et a très mal conservé ses archives. S'est donc imposé un important travail de confrontation entre sources primaires : documents reliés, registres et journaux de bord conservés à la Bibliothèque-musée de l'Opéra (Bibliothèque nationale de France), feuillets et liasses conservés aux Archives nationales (fonds $\mathrm{O}^{1}$ ou $\mathrm{AJ}^{13}$ ) et sources secondaires (livrets, presse, etc.). effect of novelty by revealing the general context in which the creations took place; and to expose how the Opéra developed its artistic strategy by comparing its directors' intentions and those of the various individuals responsible for production. Chronopéra was then conceived as a practical and easily accessible tool for researchers. Its content being constantly enriched, this database is at the crossroads of two fields of research that are too often separate - institutional history and the history of performing arts. Chronopéra is thus essential as a documentary resource and an indispensable tool for historians of music, dance, and performance.

\section{How was the corpus defined?}

Chronopéra provides the daily programme of the Opéra de Paris from its inception in 1669 until 1989, year of the opening of the Opéra Bastille. It is therefore a closed and homogenous corpus, with boundaries that can be easily justified since the Opéra de Paris built its repertoire from the start as a resource in which shows remain on a long-term basis. The directory was not, however, easy to compile from an archival perspective because, unlike other major cultural institutions such as the Comédie-Française, the Opéra de Paris did not benefit from consistent management, nor did it do a very good job of preserving its archives. Major work was therefore required to compare primary sources: documents in binders, registers, and logbooks kept at the Bibliothèque Musée de l'Opéra (Bibliothèque nationale de France), but also leaflets and bundles of paper kept at the Archives nationales (in the $\mathrm{O}^{1}$ or $\mathrm{AJ}^{13}$ collections), and secondary sources (libretti, newspapers, etc.) 


\section{La constitution de la base de données s'appuie-t-elle sur un ancrage théorique et/ou disciplinaire précis ?}

Chronopéra a pour objectif de démontrer que l'étude des phénomènes musicaux peut et doit passer par l'étude des phénomènes extramusicaux, dans une démarche d'histoire sociale de la musique. Elle fait apparaître non seulement des renseignements formels sur les œuvres (genre, nombre d'actes, etc.) mais également le système de contraintes multiples (financières avec les recettes journalières, matérielles avec les salles de spectacles, etc.) dans lequel ces œuvres sont produites, en les reliant à des questions plus larges de réception et d'esthétique (programmation en fonction des jours de la semaine ou des saisons théâtrales par exemple). Avant l'éclosion récente de plusieurs bases de données d'envergure consacrées à d'autres institutions culturelles (Dezède, le Projet des registres de la Comédie-Française), Chronopéra a été un outil pionnier.

\section{Quels logiciels avez-vous utilisés pour bâtir l'infrastructure de la base de données et, le cas échéant, pour son exploitation statistique?}

Chronopéra fonctionne avec le logiciel libre MySQL qui permet une mise en ligne aisée et gratuite, et est interrogeable au moyen du langage de requête SQL. Comme cette utilisation n'est accessible qu'à l'utilisateur qui possède des connaissances avancées en SQL et une bonne vision de l'articulation des diverses tables de la base de données, une interface conviviale, via un site Internet, a été progressivement mise en place. Cette dernière permet d'effectuer la plupart des requêtes classiques : affichage du calendrier pour une période définie, des œuvres d'un compositeur, d'un librettiste ou

\section{Is the design of the database supported by a specific theory and/or discipline?}

Chronopéra seeks to demonstrate that the study of musical phenomena can and must include the study of extra-musical phenomena within a social history of music approach. It reveals not only formal information concerning the works (genre, number of acts, etc.), but also the system of multiple constraints (financial - due to the daily takings, material - relating to entertainment facilities, etc.) in which they were produced, by connecting them to larger issues of reception and aesthetics (programming according to the days of the week or theatre seasons, for example). Prior to the recent creation of several large-scale databases dedicated to other cultural institutions (Dezède, the Comédie-Française Registers Project, Chronopéra was a pioneering tool.

\section{Which software programs were used to build the database infrastructure and, as the case may be, to treat the data statistically?}

Chronopéra works with MySQL, a free software which allows easy online access at no cost, and is searchable by way of SQL query language. As this use is only accessible to users with advanced knowledge in SQL and a good sense of the structuring of various database tables, a user-friendly interface via an internet site was gradually installed. It allows most standard searches to be carried out: display of the calendar for a given period; or of the works of a composer, a librettist, or a choreographer. The results of these different searches can be sorted according to several criteria and 
d'un chorégraphe. Les résultats de ces diverses requêtes peuvent être triés selon plusieurs critères et exportés vers différents formats (pdf, xls et csv). Le mode de recherche expert via l'emploi de requêtes SQL permet d'exploiter toute la puissance de Chronopéra, à l'aide de requêtes multicritères sur les diverses tables constituant la base de données. Il est par exemple possible de générer une table des compositeurs, classés selon la recette moyenne que produisent leurs œuvres pendant une période donnée. On peut enfin déterminer quels sont les jours de la semaine les plus prolifiques, si certains mois sont désertés par le public et si ces phénomènes connaissent des évolutions au cours des siècles.

\section{Pourriez-vous donner en exemple un ou deux résultats scientifiques (attendu ou surprenant) obtenus à l'aide de la base de données ?}

Étant spécialiste del'histoire del'Académie royale de musique dans la deuxième moitié du XVIII ${ }^{e}$ siècle, j'ai mené une analyse fine et systématique des données contenues dans Chronopéra pour cette période. II est par exemple apparu que la programmation du répertoire obéissait à trois grands principes. Le premier est celui des «longues séries », appliqué dans un but essentiellement économique : une même œuvre est jouée plusieurs fois par semaine pendant plusieurs semaines. Le deuxième est celui de l'alternance, entre les différents genres lyriques et chorégraphiques, ou entre les différents titres au cours de la saison ou au cours des mois et des semaines : dans ce cas, il s'agit de permettre le meilleur compromis entre les inclinations artistiques de la maison et celles du public. Enfin, le troisième est celui des «spectacles couplés ", composés d'extraits d'œuvres populaires qui étaient représentées les unes à la suite des autres sans tentative de les lier entre eux : la pratique, peu coûteuse, offre l'avantage de plaire au public sans user le grand exported to different formats (.pdf, .xls, or .csv). The expert search method, via the use of SQL searches, allows full exploitation of the Chronopera database with the help of multi-criteria searches on the various tables it comprises. It is, for example, possible to generate a table of composers sorted according to the average revenue per performance during a given period. Finally, one can identify which days of the week were the most prolific, whether there were certain months during which the public did not attend, and the evolution of these phenomena over the centuries.

\section{Could you offer one or two examples of scientific (whether consensual or surprising) results obtained with the help of the database?}

Being a specialist in the history of the Académie royale de musique in the second half of the eighteenth century, I conducted a detailed and systematic analysis of the data contained in Chronopéra for that period. It became apparent, for example, that the programming of the repertoire adhered to three major principles. The first was that of the "long series," applied for essentially economic purposes - the same work would be performed several times a week for a number of weeks. The second was that of alternating between different operatic and choreographic genres, or between different titles during the season or over months or weeks. In this case, it was about finding the best compromise between the house's artistic inclinations and those of the public. The third was that of "coupled performances," composed of extracts from popular works that were performed one after the other without an attempt to connect one to the other. This inexpensive practice offered the advantage of pleasing audiences without exhausting the considerable financial 
opéra pour lequel des moyens financiers et humains considérables étaient investis. Par conséquent, on voit comment la programmation du répertoire est une procédure particulièrement complexe qui requiert coordination, arbitrage et contrôle, et comment, dans ce contexte, la liberté artistique des directeurs de la maison apparaît comme instable et fluctuante.

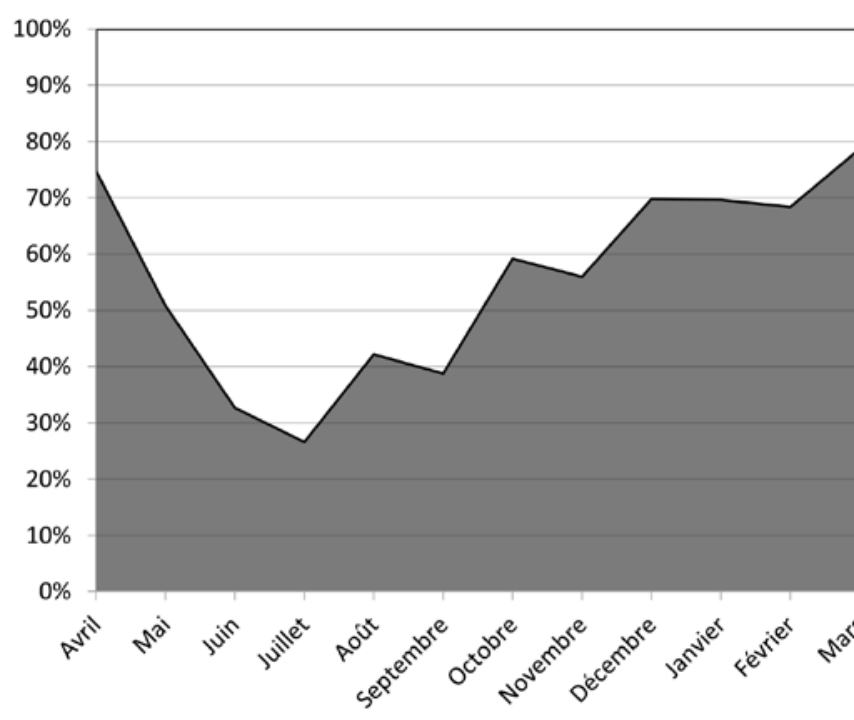

and human resources that had been invested in the grand opéra. This therefore shows how the programming of the repertoire was a particularly complex procedure that required coordination, arbitration, and control; and how, in this context, the artistic freedom of house directors appears unstable and fluctuating.
Figure 1. Ratio moyen par mois entre les œuvres lyriques et chorégraphiques à 'Académie royale de musique (1749-1791) Graphique élaboré à partir de l'analyse des registres de comptabilité de l'Académie royale

$$
\text { de musique conservés à la Bibliothèque- }
$$
musée de l'Opéra Garnier (cote : CO2-CO25).

On voit bien comment les règlements de 1714 qui préconisaient de réserver l'hiver et le printemps aux tragédies lyriques, et l'automne plutôt aux ballets, ont été respectés : tout au long de la période, la saison privilégiée du genre lyrique s'étend d'octobre à avril et celle du genre chorégraphique de mai à septembre. Les mois où l'alternance est la plus pratiquée sont les mois de mai, d'octobre et de novembre.
It is clear that the 1714 regulations that recommended reserving winter and spring for operatic tragedies, and autumn for ballet were respected. Throughout the period, the season in which the operatic genre was preferred runs from October to April, and that of the choreographic genre from May to September. The months in which alternating is practised the most are May, October, and November. 


\section{Qu'envisagez-vous pour la pérennité et l'accessibilité de la base de données ?}

Dans un premier temps, il convient de relancer Chronopéra, qui est restée inactive depuis 2012, faute de temps et de personnel. Cette nouvelle impulsion se fera dans plusieurs directions : vérification des données existantes, reconstitution de la chronologie des représentations pour la période 1672-1749, ajout aux données chronologiques des données concernant la distribution, alignement vers les notices d'autorité $\mathrm{BnF}$ réalisées pour les œuvres, les spectacles, les salles de spectacles et les personnes. Parallèlement à ce travail, une nouvelle version de Chronopéra, plus fonctionnelle et agréable pour l'utilisateur en termes d'ergonomie, sera élaborée. Dans un second temps, la pérennisation de la base sera garantie par son intégration à la TGIR - Très grande infrastructure de recherche - Huma-Num, ainsi que par la préparation d'un ouvrage papier sur le modèle du Théâtre de l'Opéra-Comique Paris. Répertoire 1762-1972 de David Charlton et Nicole Wild (2005). Enfin, des liens, permis par l'interopérabilité des données, seront faits avec des projets similaires dans le champ de l'histoire des spectacles, en particulier avec le Projet des registres de la Comédie-Française.

$$
\begin{array}{r}
\text { Solveig Serre } \\
\text { CNRS - Centre d'études supérieures de la Renaissance (CESR/CMBV) }
\end{array}
$$

\section{Références bibliographiques}

Charlton David \& WILD Nicole (2005). Théâtre de l'Opéra-Comique Paris. Répertoire 1762-1972. Bruxelles, Mardaga.

\section{What plans do you have with regard to the perpetuity and accessibility of this database?}

First of all, it is a good time to relaunch Chronopéra, which has been inactive since 2012 because of time and staffing issues. This new momentum will take several forms: the verification of existing data; the reconstitution of the chronology of performances from 1672 to 1749; the addition of distribution data to chronological data; and alignment on the authority records issued by the $\mathrm{BnF}$ for works, performances, performance halls, and individuals. Parallel to this work, a new, more functional and user-friendly version of Chronopéra will be developed. Then, the perpetuity of the database will be guaranteed by its integration into the "Very Large (digital) Facility" Huma-Num, as well as by the preparation of a print document modelled on the book Théâtre de l'OpéraComique Paris. Répertoire 1762-1972 by David Charlton and Nicole Wild (2005). Finally, links permitted by the interoperability of the data will be made to similar projects in the field of the history of performing arts, in particular to the Comédie-Française Registers Project.

Solveig Serre

CNRS - Centre d'études supérieures de la Renaissance (CESR/CMBV)

\section{References}

ChARLton David \& WiLd Nicole (2005). Théâtre de l'Opéra-Comique Paris. Répertoire 1762-1972. Brussels, Mardaga. 